\title{
Understanding the local biodiversity and open space strategies in two South African cities
}

\author{
Quraisha Bux ${ }^{1}$, Pippin Anderson ${ }^{1}$ and Patrick J. O'Farrell ${ }^{2}$
}

\begin{abstract}
South Africa is the third most biologically diverse country in the world. Urban living places pressure on this biodiversity and the ecosystem services that flow from it. Local governments are now internationally recognized as the level of government that is key to securing long-term global sustainability. The cities of Cape Town and Durban in South Africa have each developed their own biodiversity and open space conservation strategies to protect the remaining biodiversity within their municipal boundaries. Our aim was to explore the local biodiversity and open space conservation strategies in these two cities, with a view to understanding the informants and emerging forms of urban conservation in these cities in light of their variable biophysical templates and settlement histories. The results reveal that both cities are facing biodiversity loss and that multiple interlinked factors play a role in the development and relative success of conservation plans. These factors include the local context, biophysical templates, city histories, social aspects that determine how these plans emerge and evolve, contemporary governance structures, and locally relevant pressures. Biodiversity conservation in South African cities will continue to face many challenges, and our study suggests that solutions will need to be city specific.
\end{abstract}

Key Words: biodiversity; cities; conservation; local government; urbanization

\section{INTRODUCTION}

Cities are home to more than half of the world's population and are responsible for a disproportionately large ecological footprint. Cities represent complex, interlinked systems shaped by dynamic interactions between ecological and social systems (Elmqvist et al. 2013). Many urban areas contain high levels of indigenous biodiversity and are in or near biodiversity hotspots (Miller and Hobbs 2002, Mittermeier et al. 2011, Beninde et al. 2015, McLean et al. 2016). Urban biodiversity has been defined as the variety and richness of living organisms and habitats found in and on the edge of human settlements (Müller et al. 2010). Indigenous biodiversity and green open spaces provide a myriad of benefits to city dwellers through the provision of ecosystem goods and services (O'Farrell et al. 2012, Cilliers et al. 2013, Madureira et al. 2015), creating stepping stones to nonurban habitats, facilitating responses to environmental change, stabilizing local climate, improving biophysical conditions, and bolstering human well-being (Barbosa et al. 2007, Dearborn and Kark 2010, Wright Wendel et al. 2012). Urbanization affects biodiversity both directly through physical expansion over land and indirectly via land use and human behaviors within urban areas (Güneralp et al. 2013). Urbanization presents new challenges for biodiversity conservation and directly contributes to the main drivers of biodiversity loss, along with habitat loss, overexploitation, and the introduction of invasive alien species (Puppim de Oliveira et al. 2011).

South Africa, encompassing 1.22 million $\mathrm{km}^{2}$ on the southern tip of Africa, is the third most biologically diverse country in the world (Wynberg 2002, Wilhelm-Rechmann and Cowling 2013). It is characterized by an array of landscapes and ecosystems, a great diversity of species and marine and coastal systems, and high levels of endemism (Wynberg 2002, Skowno et al. 2019). It is also home to three of the world's 36 biodiversity hotspots (Department of Environmental Affairs 2012, Driver et al. 2012,
Skowno et al. 2019). The country has several cities located within these biodiversity hotspots, and this biodiversity is some of the most threatened on the planet (Wynberg 2002, Department of Environmental Affairs 2012). Because of its subtropical location, South Africa experiences warm temperate conditions and is a relatively dry country.

Most South African cities, with Cape Town and Durban at the forefront, are sprawling in configuration, with deep social and spatial divides established through apartheid planning. "Urban planning under apartheid stratified settlements and access to resources and green space in the city into strict zones of different racial groups, which still persist today"(Stålhammar 2021:3). This historic planning has upheld segregation and tends to prevent access to conservation areas by underprivileged communities (Turok 2001, Stålhammar 2021).

Although many shared biodiversity and ecosystem problems are faced by and emanate from cities, these problems manifest differently in different cities (Wilkinson et al. 2013). South African cities have been shaped by common national processes but have their own distinctive features, including the natural environment; the economic, social, and cultural make-up; and current dynamics (Patel 2005). Governance, conservation efforts, and justification for action may therefore differ among cities. Because of increasing urban population growth, the importance has increased for city governance to address the challenges of biodiversity loss (Puppim de Oliveira et al. 2011). Cities have the means to integrate biodiversity into decision-making processes and policies, as well as to create new policies with a conservation agenda.

The conservation estate in South Africa falls between national, provincial, and local authorities (Bux 2018), each with different governance systems and variable conservation approaches and associated funding. Although South Africa has well-developed policies and legislation for the management and conservation of

${ }^{1}$ Department of Environmental and Geographical Science, University of Cape Town, ${ }^{2}$ FitzPatrick Institute of African Ornithology, DST/NRF Centre of Excellence, Department of Biological Sciences, University of Cape Town 
biodiversity (Skowno et al. 2019), conservation action on the ground is slow, indicating a policy-practice divide (Holmes et al. 2012). Local governments play a major role in policy implementation and development planning and are directly responsible for action on the ground. For this reason, local government is better suited than any other sphere of government in South Africa to manage biodiversity and ecosystems and has the potential to affect positive change. To protect, optimize, and enhance biodiversity and natural areas within cities, local government departments have adopted unique biodiversity and open space conservation strategies.

Here, we explore the local conservation strategies and approaches to biodiversity and open space conservation in two South African cities. We unpack how the local context informs conservation strategies in the cities of Cape Town and Durban. Although these two cities are governed by the same national legislation, they differ in their local approaches. We investigate how these strategies emerged and to what extent city histories and biophysical templates inform conservation and management at the local government level.

\section{METHODS}

We used a qualitative research approach to deepen our understanding of local biodiversity governance in Cape Town and Durban. The approach is founded on the notion of concept analysis, with data-generating methods consisting of document and policy analysis as well as semistructured interviews with city officials. The conservation plans are known as the Biodiversity Network (BioNet) in the City of Cape Town Municipality (CoCT) and the Durban Metropolitan Open Space System (D'MOSS) in the eThekwini Municipality (i.e., Durban).

\section{Study sites}

\section{Cape Town}

Cape Town, situated in the Western Cape province, is South Africa's most southwesterly city (Fig. 1). Cape Town has a warm Mediterranean climate and experiences most of its rainfall in winter. Contained within the city's $2460 \mathrm{~km}^{2}$ footprint is a diverse geography of mountain ranges, including Table Mountain National Park and the Cape Peninsula, a coastline of $>300 \mathrm{~km}$, lowland vegetated areas, 16 nature reserves (at the time of study), and a built environment (City of Cape Town 2017). Cape Town is situated in the geographically restricted Cape Floristic Region, the smallest and most diverse floral region on Earth (Holmes et al. 2012, Goodness and Anderson 2013), which exhibits high levels of endemism and threatened biodiversity (Holmes et al. 2012). Cape Town is home to four centers of fynbos plant endemism and contains 19 national terrestrial vegetation types, six of which are found nowhere else but inside the city borders (Holmes et al. 2012, City of Cape Town 2017). There are approximately 3350 indigenous plant species in the city, with 190 endemic to the city itself (Rebelo et al. 2011). The fynbos biome is a fire-dependent system (van Wilgen 2013).

Cape Town continues to grapple with poverty, unemployment, and housing and development discrepancies that are remnants of apartheid governance. Its economy is dominated by the tertiary sector as well as the retail sector and transport, storage, and communication sector (City of Cape Town 2019a). Cape Town is also a popular tourist destination, and tourism is a valuable contributor to the city's economy, which serves as an economic incentive to protect the natural habitats in the city.

Fig. 1. Location of the study areas, Cape Town and Durban, in South Africa.

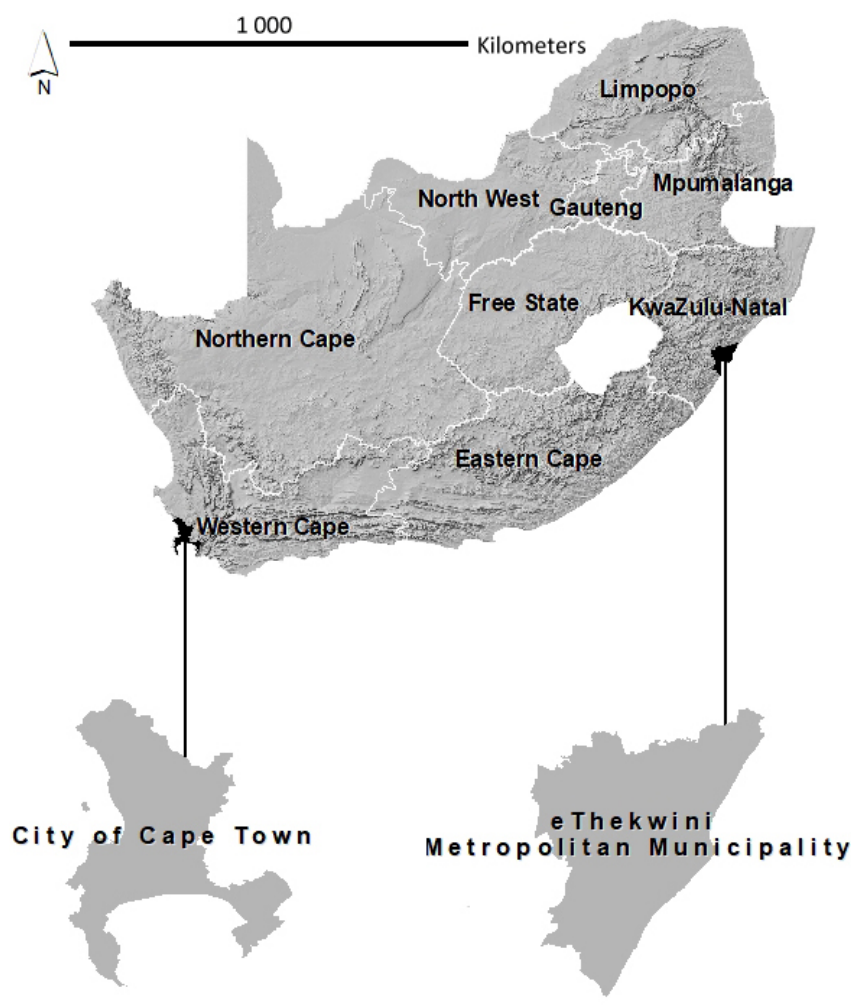

Durban

Durban is situated on the eastern seaboard of South Africa and is the largest city within the province of Kwa-Zulu Natal. Durban has a humid subtropical climate and experiences most of its rainfall in summer. The city is governed by the eThekwini Municipality, which covers an area of approximately $2556 \mathrm{~km}^{2}$. The eThekwini Municipal Area (Fig. 1) is characterized by steep escarpments in the west and coastal plains in the east. In addition, the area has $97 \mathrm{~km}$ of coastline, with 17 river catchments and 16 estuaries, which greatly increases the biodiversity within the region (eThekwini Municipality 2017a). Durban is biologically rich because it occurs within a biogeographical transition zone (eThekwini Municipality 2017a) and falls within the Maputaland-Pondoland region of floristic endemism, a global biodiversity hotspot. It also contains three of the country's nine terrestrial biomes (Savanna, Forest, and Indian Ocean Coastal belt), eleven broad nationally recognized vegetation types, and > 2200 plant species (eThekwini Municipality 2017a). Management interventions in natural areas include removal of invasive alien species and periodic burning of grassland habitats (eThekwini Municipality 2017a).

Unemployment and poverty are major issues in Durban, along with the challenges persisting from the ravages of apartheid. Durban contains large rural areas under the governance of 
traditional authorities, and a large proportion of the population lives in informal settlements (eThekwini Municipality 2017b). The biggest contributors to eThekwini's economy are the transport, storage, and communication sector, as well as manufacturing. It is also a leading South African tourist destination.

\section{Document and policy analysis}

We analyzed documentation relating to biodiversity and green open space conservation in each city (Table 1). This qualitative research method involved the systematic review, evaluation, and interpretation of documents and policies in relation to set research questions (Bowen 2009). This process was done to elicit meaning, gain understanding, and develop empirical knowledge through content and thematic analysis (Bowen 2009).

Table 1. List of documents and policies reviewed.

\begin{tabular}{|c|c|}
\hline Document or policy & Source \\
\hline $\begin{array}{l}\text { City of Cape Town Biodiversity Network: C- } \\
\text { Plan and Marxan Analysis } 2016\end{array}$ & $\begin{array}{l}\text { Holmes and Pugnalin } \\
\text { (2016) }\end{array}$ \\
\hline $\begin{array}{l}\text { City of Cape Town Local Biodiversity Strategy } \\
\text { and Action Plan 2016-2026 }\end{array}$ & $\begin{array}{l}\text { City of Cape Town } \\
\text { (2016b) }\end{array}$ \\
\hline City of Cape Town Bioregional Plan 2015 & $\begin{array}{l}\text { City of Cape Town } \\
(2015)\end{array}$ \\
\hline City of Cape Town Biodiversity Strategy 2003 & $\begin{array}{l}\text { City of Cape Town } \\
\text { (2003) }\end{array}$ \\
\hline $\begin{array}{l}\text { Durban's Biodiversity Strategy and Action Plan } \\
2017\end{array}$ & Unpublished report \\
\hline Durban's State of Biodiversity Reports & eThekwini Municipality \\
\hline $2016 / 2017$ and $2017 / 2018$ & $(2017 \mathrm{a}, 2018)$ \\
\hline $\begin{array}{l}\text { Durban's Systematic Conservation Assessment } \\
\text { Report } 2016\end{array}$ & McLean et al. (2016) \\
\hline
\end{tabular}

\section{Interviews}

Interviews were conducted to gain further insights and information from officials of local environmental departments. The interview schedule included a set of open-ended questions relating to biodiversity and open space conservation. Local government officials were selected as interview candidates because of their operational experience, their positions in the relevant biodiversity departments, and their involvement in the biodiversity and open space policies within the municipalities. The participant for CoCT was the now-former Biophysical Specialist (hereafter referred to as the CoCT official), who was directly responsible for compiling and updating the BioNet at the Biodiversity Management Branch within the Environmental Management Department in the CoCT. In Durban, two participants were selected, including the now-former Manager of the Biodiversity Planning Branch (eThekwini Municipality official 1) and a Senior Specialist Ecologist (eThekwini Municipality official 2) at the Environmental Planning and Climate Protection Department (EPCPD) in eThekwini Municipality. The responses from city officials were analyzed using well-known qualitative data analysis techniques, including thoroughly interpreting the information, taking detailed notes, identifying key themes that emerged, and organizing and grouping the information into different themes.

\section{Data analysis}

The data were analyzed and clustered into relevant themes. Findings from the document and policy analysis were triangulated against those from the interviews to capture different dimensions of the same topics (Bowen 2009). Next, we present and discuss the results obtained from these methods.

\section{RESULTS AND DISCUSSION}

\section{History and emergence of conservation strategies in Cape Town and Durban}

CoCT has numerous environmental policies relating to biodiversity management at the local level, suggesting a particularly engaged approach to biodiversity conservation. This approach dates from the Integrated Metropolitan Environmental Policy of 2001 to the Environmental Strategy of 2017. In contrast, Durban does not have as many policies relating to biodiversity conservation but did produce a Biodiversity Strategy and Action Plan in 2017 (this plan was a working document at the time of publication). D'MOSS acts as a spatial tool that steers development and is supported by Municipal Council. BioNet is also a spatial tool and is supported by associated local biodiversity policies, including Cape Town's Local Biodiversity Strategy and Action Plan and Bioregional Plan.

Cape Town

BioNet is the CoCT's regularly updated, fine-scale, systematic biodiversity plan (Fig. 2). It was informed by previous nature conservation studies and reports in the city, including the 1982 "Greening the City" report and the 1997 Botanical Society of South Africa's study, which resulted in the "Cape Flats Flora Core

Fig. 2. Map of the City of Cape Town's Biodiversity Network in 2016, which was developed using the systematic conservation planning approach. Source: City of Cape Town open data portal.

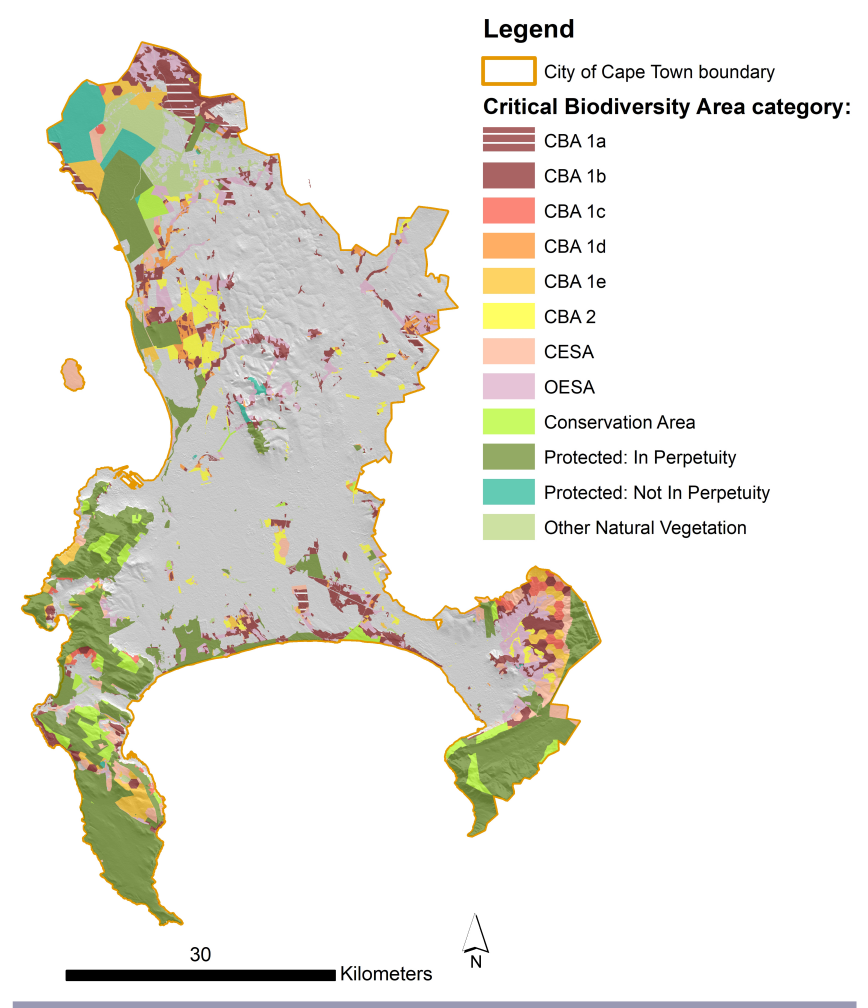


Conservation Sites" project (City of Cape Town 2003). In the early to mid-1990s, many remnants of conservation areas were lost to development while others gradually degraded because of a lack of on-the-ground management (City of Cape Town 2003).

In 2002, CoCT was the first municipality in South Africa to initiate a "systematic conservation planning" approach to prioritize natural areas efficiently to meet biodiversity pattern and process targets (Holmes et al. 2019). When interviewed, the CoCT official stated that the city decided to follow best-practice techniques, and that Cape Town was at the forefront of systematic biodiversity planning in South Africa. The identification and prioritization of the conservation network was a collaborative process between CoCT's Environmental Management Department and key conservation partners, namely the South African National Biodiversity Institute, the Botanical Society of South Africa, the Table Mountain Fund, CapeNature Conservation, provincial government departments, and several environmental specialists (City of Cape Town 2015). After identifying important tracts of remnant indigenous vegetation using existing knowledge of local government nature reserves and the best available data, conservation planning methodologies were used to define the optimal configuration for BioNet in 2004.

The objectives of BioNet are based on pure conservation reasoning (i.e., the safeguarding of species of conservation interest and their habitats) to protect and conserve Cape Town's globally significant biodiversity and to direct spatial planning away from sensitive areas. The systematic conservation planning approach (Margules and Pressey 2000) identifies remnants of land within the municipal area that need to be conserved to ensure the protection of a representative sample of key biodiversity areas. The systematic conservation planning approach represents best available science practice internationally (Margules and Sarkar 2007, McLean et al. 2016) and is the standard approach to biodiversity planning in South Africa (see South African National Biodiversity Institute: $\underline{h t t p}$ ://biodiversityadvisor.sanbi.org/planningand-assessment/environmental-assessments/what-us-bioregionalplanning/). Today, BioNet remains at the core of CoCT's strategic approach to biodiversity conservation.

\section{Durban}

D'MOSS is a system of green open spaces incorporating areas of high biodiversity value (privately and publicly owned) and comprising a variety of habitat types linked together in an ecologically viable network (eThekwini Municipality 2017a). It was informed by: the former Wildlife Society's conservation plan of 1979; various discussions with stakeholders, including town planners, nongovernmental organizations, conservationists, academics, and applied scientists; and collaborative studies, including Dr. Debra Roberts' (current Chief Resilience Officer at the eThekwini Municipality) $\mathrm{PhD}$ research, which involved an ecological assessment of open spaces within the municipal area (eThekwini Municipality 2007). The recognition of the importance of Durban's open spaces to conservationists and planners emerged in the early 1980s (McLean et al. 2016), during a time of political transformation and accelerated urbanization, with national population growth rates between $2.5 \%$ and $3 \%$ (Turok 2012). The human impacts on natural and open spaces were becoming increasingly apparent, and so was the need to protect remaining natural remnants.
In the late 1990s, Durban became the first of several South African municipalities to implement its open space system approach in urban nature conservation (Cilliers and Siebert 2012). According to McLean et al. (2016), the objectives of D'MOSS were a combination of pure conservation reasoning as well as the utilitarian interests of town planners (i.e., providing ecosystem services). Initially, D'MOSS was restricted to the central and mostly developed parts of the former Durban Metropolitan Council (McLean et al. 2016). However, the borders of Durban's municipal area expanded; in 2000, the borders were redemarcated, and the physical size of the city increased by $68 \%$ (Marx and Charlton 2003, eThekwini Municipality 2007). The D'MOSS footprint was subsequently updated to include the new boundaries, including widespread traditional authority and rural areas.

In 2016, the city realized it needed a more robust and scientific approach to identify areas for conservation. The EPCPD undertook its first systematic conservation assessment in which it adopted the principles of systematic conservation planning to identify and prioritize areas for the conservation of biodiversity and ecosystem services (McLean et al. 2016). The assessment was used to update D'MOSS (Fig. 3) and was approved by Municipal Council in late 2016. In 2017, the boundaries of the eThekwini Municipal Area expanded again (Fig. 3), and the EPCPD subsequently had to update and undertake the mapping of new conservation-worthy areas within the newly expanded region (eThekwini Municipality officials, personal communication, 04 July 2017).

Fig. 3. Map of the Durban Metropolitan Open Space System in 2016, which was developed using the systematic conservation planning approach. Green areas include Critical Biodiversity Areas and Ecological Support Areas. The eThekwini boundary expansion occurred in 2017. Source: eThekwini Municipality.

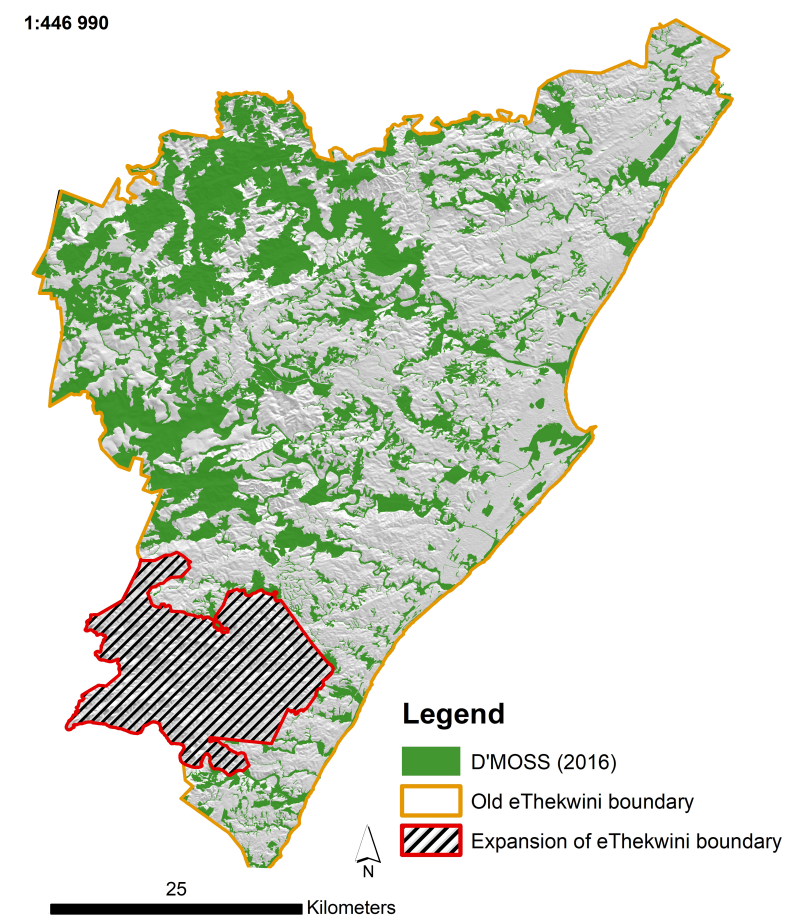


The aim of conservation plans in Cape Town and Durban is to protect and maintain the biodiversity and ecosystems services within these municipal areas. These two cities depend on ecosystem services, much like other cities across the globe, and benefit from similar services; however, in these two coastal African cities, some ecosystems are more important in providing resilience to climate change, securing water, and providing tourism benefits and coastal protection (Gómez-Baggethun et al. 2013). Durban had a broader group of specialists and organizations, including town planners and nongovernmental organizations, involved in the creation of D'MOSS, whereas those involved in Cape Town's BioNet were largely biodiversity specialists, consultants, and the city's conservation partners. Durban's town planners would have provided insight into the use of land, plans and programs for growth and development, and how D'MOSS would fit into the municipal area. Durban has also expanded considerably over the years, which highlights the changing boundaries and expansion of the eThekwini Municipal Area, which added more green spaces to the municipal area and subsequently to D'MOSS. In comparison, CoCT has only improved and updated its input data, methodology, and analysis of BioNet after it was first produced in 2004. The boundaries of Cape Town's municipal area have remained static since the "Unicity" was formed in 2000 (City of Cape Town 2017). In contrast, eThekwini Municipality has also only started using the systematic conservation planning approach recently, whereas CoCT has used the approach since BioNet's inception.

\section{The success of conservation systems}

Although the total area of biodiversity lost within Cape Town has indeed increased, the total area of biodiversity under formal protection has expanded over the past century (City of Cape Town 2016a). Cape Town is the only city in South Africa that contains a national park within its borders. Table Mountain National Park and mountainous areas of the city have always been well conserved and add approximately $30 \%$ to the BioNet being secured (CoCT official, personal communication, 26 May 2017). The presence of the mountains is significant because, due to slope and elevation, these areas cannot be developed, and the mountain range can be formally protected and conserved as a unit. In 2016, Critical Biodiversity Areas comprising natural remnants, along with critical Ecological Support Areas, covered approximately 87,206 ha of Cape Town. The BioNet was located mainly outside the urban edge, with only $15 \%$ located inside the urban edge (Holmes and Pugnalin 2016). In 2016, 60.9\% of BioNet (including both protected categories and conservation areas) had been secured and placed under conservation (CoCT official, personal communication, 26 October 2017). This achievement was considered remarkable and indicated Cape Town's commitment to long-term biodiversity conservation.

Unlike Cape Town, Durban does not have large mountainous areas that can be conserved as a unit. In 2016 , only $8.2 \%$ of the total area of the 78,781 ha of D'MOSS enjoyed some form of protection, while only $7.7 \%$ was formally managed for conservation (eThekwini Municipality 2017a). Therefore, at this time, $<3 \%$ of the entire eThekwini Municipal Area was protected. An estimated $42 \%$ of the total area of D'MOSS is physically undevelopable, and approximately $34 \%$ of the total area is in private or communal ownership (eThekwini Municipality 2017b). Although there are regions of undevelopable land, the municipality is still faced with challenges in getting these incorporated into the conservation network.

Rural areas of eThekwini Municipality make up approximately $68 \%$ of the municipal area that falls beyond the urban development line, with communal land occupancy under the ownership of the Ingonyama Trust Board and traditional authorities (eThekwini Municipality 2017c). The remainder of the municipal area is urban and dominated by residential, commercial, and industrial land uses (eThekwini Municipality 2017c).

\section{City-led conservation initiatives and implementation}

Cities in South Africa are inherently different and have unique histories, configurations, and challenges, and it is not possible or practical to be prescriptive about specific interventions and implementation strategies. Furthermore, according to Holmes et al. (2012), the full success of implementation cannot be achieved without international or national funding and political will at all levels of government.

\section{Cape Town}

BioNet is implemented by partnership with internal line functions and external stakeholders. Despite significant challenges, the CoCT's Biodiversity Management Branch has been successful in securing more of the BioNet through a range of innovative measures. A key tool in this success was to undertake both planning and implementation simultaneously. Additionally, collaboration with national and provincial conservation partners has been vital in implementing these tools. Progress is being made in implementing BioNet, but stronger political commitment is needed at all levels of government (Holmes et al. 2012). The initiatives and tools that have been used in implementing BioNet include: (1) proclaiming, securing, and managing land with biodiversity value; (2) establishing partnerships with the provincial department; (3) ecological restoration; and (4) stewardship (i.e., private land owners' commitment to conservation) agreements (CoCT official, personal communication, 26 May 2017).

\section{Durban}

eThekwini Municipality official 1 (personal communication, 04 July 2017) stated that the situation of the EPCPD being positioned within the Spatial Planning department of the municipality has been highly beneficial to the implementation of D'MOSS. This situation is a critical difference between BioNet and D'MOSS and indicates the significant role that town planning tools have for D'MOSS. The key initiatives and tools used in the implementation of D'MOSS include: (1) integrating D'MOSS into the municipality's town planning schemes, (2) using planning tools such as environmental conservation reserves and conservation zones, (3) stewardship agreements, (4) the land acquisition program, and (5) nature reserve proclamation.

The EPCPD has made considerable progress by integrating D'MOSS into the city's town planning schemes. However, eThekwini Municipality is faced with a particular challenge with regard to administration and governance of municipal land. In 2016, 38\% of eThekwini Municipal Area was jointly governed by the eThekwini Municipality and the traditional authority, the Ingonyama Trust Board, with primary responsibilities falling under the latter (Boon et al. 2016, World Bank 2016; eThekwini 
Municipality official 1, personal communication, 04 July 2017). At that time, the Ingonyama Trust land covered approximately 2.7 million ha throughout Kwa-Zulu Natal (World Bank 2016). Most areas under the Ingonyama Trust are of high biodiversity value (eThekwini Municipality official 1, personal communication, 04 July 2017). Approximately 50\% of D'MOSS, which requires protection, is located within communal lands (eThekwini Municipality 2017c). Unfortunately, there is a high level of distrust, which, in the city's view, makes securing these biodiversity-rich sites particularly challenging (eThekwini Municipality official 2, personal communication, 04 July 2017). There are also new residential developments emerging without development restrictions or planning in these regions, resulting in the rapid transformation and loss of biodiversity (Davids et al. 2016).

In rural areas under traditional authority leadership, customary land management systems are exercised. Currently, there are no land-use schemes in traditional authority areas, and because D'MOSS is a provision of the town planning schemes, traditional allocation of land for residential use in these areas can bypass D'MOSS approval (Sutherland et al. 2016). Outside of land-use scheme areas, there is no way to regulate, manage, or stop developments. However, the EPCPD is trying to establish biodiversity stewardship agreements with traditional leaders (eThekwini Municipality official 2, personal communication, 04 July 2017).

Khan et al. (2006:86) state, "eThekwini Municipality is unique as it represents the only urban environment in the country in which adaptation to co-operative forms of governance involving traditional leaders is being tested out at a metropolitan level". This institutional arrangement in the eThekwini Municipal Area presents several challenges, particularly with respect to land, planning, and urban management (Sutherland et al. 2016, eThekwini Municipality 2017c). The governance structures in Cape Town and Durban are different, with Cape Town having no dual governance of municipal land, whereas eThekwini Municipality must navigate a more complex system of dual governance to protect remnant biodiversity.

\section{Challenges faced in implementing biodiversity and open space strategies in Cape Town and Durban}

Despite legislation and policies relating to biodiversity in South Africa, a clear biodiversity mandate, resources, and capacity for biodiversity management at the local level are lacking (Holmes et al. 2012). It is also important to note that there are varied social views and values of biodiversity and green spaces, and implementing biodiversity and open space strategies is a difficult task. The following are some of the noted challenges faced by these cities in terms of implementation, and each warrants further investigation, particularly in the context of each city.

\section{Stewardship agreements, acquisition, and management} interventions

Stewardship, a means of addressing social-ecological sustainability challenges from the local to the global level, is put into practice in diverse ways worldwide (Bennett et al. 2018, Cockburn et al. 2019). Many environmentally sensitive areas in Cape Town and Durban are under threat from development. These areas are privately or communally owned and cannot easily be acquired or protected. Privately owned land usually makes up a significant proportion of the municipal area and green space network. This situation can present challenges, as captured in the following statement: "In Cape Town, there are many landowners who own large tracts of conservation-worthy land, who are not interested in entering into stewardship agreements with the city. This is due to landowners' development aspirations, and results in land with high biodiversity value being lost and degraded" (CoCT official, personal communication, 26 May 2017).

In Durban, a high proportion of D'MOSS occurs in traditional areas, and the city must attempt to establish stewardship agreements with the traditional councils to protect these areas. Funding for stewardship sites to assist with ecological management can play an incentivizing role for landowners to set aside land for conservation (City of Cape Town 2019b). Management interventions are particularly important in preventing further degradation and transformation and in maintaining ecosystems. Raising funds for these interventions remains a challenge. However, in Cape Town, the Table Mountain Fund, for example, has been exceptional in its support for Cape Town's Protected Area Expansion program (City of Cape Town $2019 b)$.

Land acquisition is another important method for securing environmentally significant areas, especially when there are no other options available. Challenges are present both in acquiring land, though sometimes budgeted for in municipalities, and also in finding funds to provide appropriate management. This situation is captured in the following statement: "Another challenge presented to municipalities are the costs associated with acquiring conservation-worthy land and the subsequent management and protection of that land" (CoCT official, personal communication, 26 May 2017).

\section{Restricting development}

The effect of having D'MOSS integrated into town planning schemes is that land is subject to development restrictions to maintain environmental integrity. These restrictions are often a problem for private landowners: "In Durban, many people view the D'MOSS as 'exclusionary' because it restricts people from developing on their land and is seen as taking away people's rights" (eThekwini Municipality official 2, personal communication, 04 July 2017). This situation makes D'MOSS unpopular in the eyes of developers.

\section{Gaining and maintaining political support}

The challenge of gaining and maintaining political support for conservation is present in both cities. Despite commitments to biodiversity conservation, conflicts between protecting biodiversity and urgent development needs are acute (Gordon et al. 2009). In most cases, decisions tend to favor and maximize socioeconomic outcomes, sometimes at the expense of ecological integrity (Holmes et al. 2012). This situation is a major challenge and suggests that there may be some internal conflict within local government between competing policies and interests from different departments. Given the competing needs for both municipal resources and land, political endorsement and a receptive political and institutional environment for the protection of natural space is crucial (ICLEI - Local Governments for Sustainability 2012). 
Traditional authorities and dual governance of land

Dual governance between a traditional authority and a municipality (e.g., Durban) is complex because the organizations operate under separate administrative regimes, and their planning and implementation systems are not always aligned (World Bank 2016). Traditional authorities are required to inform and seek counsel from the municipality on land-use decisions. However, such coordination does not always occur. Local governments, in turn, are not to interfere with traditional land without prior consultation with the relevant authority, who would need to consult with the members of the community (Traditional Authorities Research Group 1999).

Governance of biodiversity and open space conservation

The separation of different local government departments and functions, which have influence on the environment, provides a significant challenge in both cities. The environmental agenda of cities is intertwined with multiple competing priorities and interests, as well as multiple temporal and spatial scales of ecosystem processes and their relation to numerous influencing and affected actors (ICLEI - Local Governments for Sustainability 2012). Furthermore, public institutions also experience a lack of cooperation and coordination across departments and levels of authority, which presents a challenge (Elmqvist et al. 2013).

In addition, the extensive range of legislation and regulatory actions involving various aspects of natural resource management, together with the three-tier system of government in South Africa (national, provincial, and local) have resulted in a number of departments and agencies being responsible for environmental conservation and protected area management (Pool-Stanvliet et al. 2017). A further problem is created by having conflicting policies in different sectors (Holmes et al. 2012).

\section{Local influence of conservation systems in each city}

Although BioNet does not yet have legal status to serve in the protection of natural land, it does serve as an important steering mechanism during the environmental impact assessment process and has been incorporated into the city's Spatial Development Framework (SDF), eight spatial development plans, and accompanying environmental management frameworks (Holmes et al. 2012, Goodness and Anderson 2013), thus establishing a foundation for future implementation action. BioNet was further considered when devising the Western Cape's Spatial Biodiversity Framework (2010), and has been fully integrated into the Western Cape's Biodiversity Spatial Plan (2017). Although much has been done to integrate the plan, there is still scope to better embed BioNet: "While the BioNet does inform the Integrated Development Plan, SDF, and district plans of the city, it does not preclude development, since the municipal town planning schemes and relevant zoning schemes have more power than the SDF" (CoCT official, personal communication, 26 May 2017).

Similar to BioNet, D'MOSS does not have legal status to serve in the protection of natural space, but it is incorporated into the city's Integrated Development Plan (since its early development), SDF, regional spatial development plans, and into eThekwini Municipal town planning schemes as a controlled development layer (since 2010; Roberts and O'Donoghue 2013, eThekwini Municipality 2017a). That was the first time a major metropole in South Africa had officially incorporated its open space plan into the city's town planning schemes (Boon et al. 2016, Davids et al. 2016). The integration of spatial conservation assessments in these land-use processes is effective for conserving biodiversity outside protected areas (Wilhelm-Rechmann and Cowling 2013). However, D'MOSS is not a formal zone within the planning schemes and therefore does not entirely preclude development. Rather, D'MOSS assists landowners with planning the development and management of their properties and serves to clarify if there are significant biodiversity assets on their land (eThekwini Municipality official 2, personal communication, 04 July 2017). If the D'MOSS layer is situated on a piece of land, development may not occur without first obtaining environmental authorization or support from the municipality.

The presence of the EPCPD in the Spatial Planning Division, getting D'MOSS included in the Integrated Development Plan and SDF at an early stage, and the integration of D'MOSS into the full hierarchy of municipal spatial plans are some of the major differences between the CoCT and eThekwini Municipality. These aspects, and particularly the integration of D'MOSS into eThekwini's town planning schemes, means that the conservation plan is playing a key role at the local level, potentially more than that for BioNet in Cape Town.

\section{CONCLUSION}

Local governments are taking the lead in the action toward biodiversity conservation, which can be seen in these respective municipalities. However, in South Africa, a clear biodiversity mandate and resources and capacity for biodiversity management are lacking at the local level. This situation presents challenges to biodiversity conservation in the country.

The cities of Cape Town and Durban are doing extensive work to conserve, protect, and manage their remaining biodiversity and open spaces. Although BioNet and D'MOSS have emerged along very different lines, their primary aim and objectives are centred on biodiversity and open space conservation and the continued provision of ecosystem services. The two municipalities make use of systematic conservation planning methodology for their analyses, use similar implementation tools, and face a few similar challenges in implementing conservation policies at the local level. However, the cities differ with regard to their development histories, local environmental policies, influence of conservation policies at the local level, and status and success of conservation systems, as well as in their biophysical templates and land governance. All of these factors need to be considered when initiating policies and management actions. Therefore, given the unique characteristics and development histories of cities, biodiversity conservation solutions will need to be city specific.

Responses to this article can be read online at: https://www.ecologyandsociety.org/issues/responses. php/12498

\section{Acknowledgments:}

We gratefully acknowledge the city officials from the City of Cape Town and e Thekwini Municipality who participated in this research. We also thank Mthobisi Wanda for creating the locality map and conservation plan maps. 


\section{Data Availability:}

The data and code that support the findings of this study are available on request from the corresponding author, $Q$ Bux. The data and code are not publicly available because of restrictions ( $e$. $g$., containing information that could compromise the privacy of research participants).

\section{LITERATURE CITED}

Barbosa, O., J. A. Tratalos, P. R. Armsworth, R. G. Davies, R. A. Fuller, P. Johnson, and K. J. Gaston. 2007. Who benefits from access to green space? A case study from Sheffield, UK. Landscape and Urban Planning 83(2-3):187-195. https://doi. org/10.1016/j.landurbplan.2007.04.004

Beninde, J., M. Veith, and A. Hochkirch. 2015. Biodiversity in cities needs space: a meta-analysis of factors determining intraurban biodiversity variation. Ecology letters 18(6):581-592. https://doi.org/10.1111/ele.12427

Bennett, N. J., T. S. Whitty, E. Finkbeiner, J. Pittman, H. Bassett, S. Gelcich, and E. H. Allison. 2018. Environmental stewardship: a conceptual review and analytical framework. Environmental Management 61(4):597-614. https://doi.org/10.1007/s00267-017-0993-2

Boon, R., J. Cockburn, E. Douwes, N. Govender, L. Ground, C. Mclean, C., D. Roberts, M. Rouget, and R. Slotow. 2016. Managing a threatened savanna ecosystem (KwaZulu-Natal Sandstone Sourveld) in an urban biodiversity hotspot: Durban, South Africa. Bothalia: African Biodiversity and Conservation 46(2):a2112. https://doi.org/10.4102/abc.v46i2.2112

Bowen, G. A. 2009. Document analysis as a qualitative research method. Qualitative Research Journal 9(2):27-40. https://doi. org/10.3316/QRJ0902027

Bux, Q. 2018. Understanding urban ecologies in the context of local biodiversity and open space conservation agendas in two South African cities. Thesis. University of Cape Town, Cape Town, South Africa. [online] URL: http://hdl.handle. net/11427/30062

Cilliers, S., J. Cilliers, R. Lubbe, and S. Siebert. 2013. Ecosystem services of urban green spaces in African countries - perspectives and challenges. Urban Ecosystems 16(4):681-702. https://doi. org/10.1007/s11252-012-0254-3

Cilliers, S. S., and S. J. Siebert. 2012. Urban ecology in Cape Town: South African comparisons and reflections. Ecology and Society 17(3):33. https://doi.org/10.5751/ES-05146-170333

City of Cape Town. 2003. City of Cape Town biodiversity strategy. Environmental Planning Department, City of Cape Town, Cape Town, South Africa.

City of Cape Town. 2015. The Cape Town bioregional plan (policy number 44854). Environmental Resource Management Department, City of Cape Town, Cape Town, South Africa. [online] URL: https://resource.capetown.gov.za/document centre/ Documents/Bylaws $\% 20$ and $\% 20$ policies/Bioregional Plan CCTFINAL 2015-08-19 policy number_44854.pdf

City of Cape Town. 2016a. State of Cape Town report 2016: overview with infographics. Integrated Strategic Communications,
Branding and Marketing Department, City of Cape Town, Cape Town, South Africa. [online] URL: https://resource.capetown. gov.za/documentcentre/Documents/City $\% 20$ research $\% 20$ reports $\%$ 20and $\% 20$ review $/ 16429 \% 20$ CCT $\% 20$ State $\% 20$ of $\% 20$ Cape $\% 20$ Town $\%$ 20Report $\% 202016 \% 20-\% 20$ Summary $\% 20$ Report $\% 20$ V7.pdf

City of Cape Town. 2016b. Local biodiversity strategy and action plan. Environmental Resource Management Department, City of Cape Town, Cape Town, South Africa. [online] URL: https:// www.capetown.gov.za/Explore\%20and\%20enjoy/nature-and-outdoors/ Be-an-eco-tourist/Our-conservation-strategies-and-plans

City of Cape Town. 2017. Environmental strategy for the City of Cape Town (policy number 46612). Environmental Resource Management Department, City of Cape Town, Cape Town, South Africa. [online] URL: https://resource.capetown.gov.za/ documentcentre/Documents/Bylaws $\% 20$ and $\% 20$ policies/Environmental $\%$ 20Strategy.pdf

City of Cape Town. 2019a. City of Cape Town integrated annual report 2018/19. City of Cape Town, Cape Town, South Africa. [online] URL: https://resource.capetown.gov.za/documentcentre/ Documents/

City $\% 20$ research $\% 20$ reports $\% 20$ and $\% 20$ review/CCT Annual Report 2018 19.pdf

City of Cape Town. 2019b. Biodiversity management progress report July 2018 - June 2019. Environmental Management Department, City of Cape Town, Cape Town, South Africa. [online] URL: https://resource.capetown.gov.za/documentcentre/ Documents/

City\%20research\%20reports\%20and\%20review/BiodiversityManagementProgressReport Jul2018-Jun2019.pdf

Cockburn, J., G. Cundill, S. Shackleton, and M. Rouget. 2019. The meaning and practice of stewardship in South Africa. South African Journal of Science 115(5-6). https://doi.org/10.17159/ sajs.2019/5339

Davids, R., M. Rouget, R. Boon, and D. Roberts. 2016. Identifying ecosystem service hotspots for environmental management in Durban, South Africa. Bothalia: African Biodiversity and Conservation 46(2):a2118. https://doi. org/10.4102/abc.v46i2.2118

Dearborn, D. C., and S. Kark. 2010. Motivations for conserving urban biodiversity. Conservation Biology 24(2):432-440. https:// doi.org/10.1111/j.1523-1739.2009.01328.x

Department of Environmental Affairs. 2012. Biodiversity and ecosystem health. Pages 106-131 in 2nd South Africa environment outlook: a report on the state of the environment. Department of Environmental Affairs, Pretoria, South Africa. [online] URL: https://www.environment.gov.za/sites/default/files/reports/ environmentoutlook chapter7.pdf

Driver, A., K. J. Sink, J. L. Nel, S. Holness, L. van Niekerk, F. Daniels, Z. Jonas, P. A. Majiedt, L. Harris, and K. Maze. 2012. National biodiversity assessment 2011: an assessment of South Africa's biodiversity and ecosystems. Synthesis Report. South African National Biodiversity Institute and Department of Environmental Affairs, Pretoria, South Africa. [online] URL: http://catalog.ipbes.net/system/assessment/195/references/files/570/ original/NBA_2011_Synthesis_Report_\%28low_resolution\%29.pdf? $\underline{1364385861}$ 
Elmqvist, T., M. Fragkias, J. Goodness, B. Güneralp, P. J. Marcotullio, R. I. McDonald, S. Parnell, M. Schewenius, M. Sendstad, K. C. Seto, C. Wilkinson, M. Alberti, C. Folke, N. Frantzeskaki, D. Haase, M. Katti, H. Nagendra, J. Niemelä, S. T. A. Pickett, C. L. Redman, and K. Tidball. 2013. Stewardship of the biosphere in the urban era. Pages 719-746 in T. Elmqvist, M. Fragkias, J. Goodness, B. Güneralp, P. J. Marcotullio, R. I. McDonald, S. Parnell, M. Schewenius, M. Sendstad, K. C. Seto, and C. Wilkinson, editors. Urbanization, biodiversity and ecosystem services: challenges and opportunities. Springer, Dordrecht, The Netherlands. https://doi.org/10.1007/978-94-007-7088-1_33

eThekwini Municipality. 2007. LAB biodiversity report: Durban. eThekwini Municipality and ICLEI Africa Secretariat, Durban, South Africa. [online] URL: https://cbc.iclei.org/wp-content/ uploads/2016/09/Durbans-Biodiversity-Report-2007.pdf

eThekwini Municipality. 2017a. Durban: state of biodiversity report: 2016/2017. Environmental Planning and Climate Protection Department, Durban, South Africa. [online] URL: http://www.durban.gov.za/City Services/development planningmanagement/

environmental planning climate protection/Publications/Documents/ $\underline{\text { StateofBiodiversityReport.pdf }}$

eThekwini Municipality. 2017b. Integrated development plan 2017/2018. 5 year plan: $2017 / 18$ to 2021/22. Spatial Planning Department, eThekwini Municipality, Durban, South Africa. [online] URL: http://www.durban.gov.za/City Government/ City Vision/IDP/Documents/IDP\%202017\%202018.PDF

eThekwini Municipality. 2017c. Municipal spatial development framework 2017/2018-2021/2022. Final report. Spatial Planning Department, eThekwini Municipality, Durban, South Africa. [online] URL: http://www.durban.gov.za/City Services/

development planning management/

Documents/FINAL \%20SDF\%202017-2018\%20May\%202017.pdf

eThekwini Municipality. 2018. Durban: state of biodiversity report: 2017/2018. Environmental Planning and Climate Protection Department, Durban, South Africa. [online] URL: http://www.durban.gov.za/City Services/development planningmanagement/

environmental planning climate protection/Publications/Documents/ StateofBiodiversity2017 18.pdf

Gómez-Baggethun, E., Å. Gren, D. N. Barton, J. Langemeyer, T. McPhearson, P. O'Farrell, E. Andersson, Z. Hamstead, and P. Kremer. 2013. Urban ecosystem services. Pages 175-251 in T. Elmqvist, M. Fragkias, J. Goodness, B. Güneralp, P. J. Marcotullio, R. I. McDonald, S. Parnell, M. Schewenius, M. Sendstad, K. C. Seto, and C. Wilkinson, editors. Urbanization, biodiversity and ecosystem services: challenges and opportunities. Springer, Dordrecht, The Netherlands. https://doi. org/10.1007/978-94-007-7088-1 11

Goodness, J., and P. M. L. Anderson. 2013. Local assessment of Cape Town: navigating the management complexities of urbanization, biodiversity, and ecosystem services in the Cape Floristic Region. Pages 461-484 in T. Elmqvist, M. Fragkias, J. Goodness, B. Güneralp, P. J. Marcotullio, R. I. McDonald, S.
Parnell, M. Schewenius, M. Sendstad, K. C. Seto, and C. Wilkinson, editors. Urbanization, biodiversity and ecosystem services: challenges and opportunities. Springer, Dordrecht, The Netherlands. https://doi.org/10.1007/978-94-007-7088-1_24

Gordon, A., D. Simondson, M. White, A. Moilanen, and S. A. Bekessy. 2009. Integrating conservation planning and land use planning in urban landscapes. Landscape and Urban Planning 91(4):183-194. https://doi.org/10.1016/j.landurbplan.2008.12.011

Güneralp, B., R. I. McDonald, M. Fragkias, J. Goodness, P. J. Marcotullio, and K. C. Seto. 2013. Urbanization forecasts, effects on land use, biodiversity, and ecosystem services. Pages 437-452 in T. Elmqvist, M. Fragkias, J. Goodness, B. Güneralp, P. J. Marcotullio, R. I. McDonald, S. Parnell, M. Schewenius, M. Sendstad, K. C. Seto, and C. Wilkinson, editors. Urbanization, biodiversity and ecosystem services: challenges and opportunities. Springer, Dordrecht, The Netherlands. https://doi. org/10.1007/978-94-007-7088-1 22

Holmes, P. M., P. Anderson, A. Pugnalin, J. Wood, and C. Dorse. 2019. Conservation planning for climate change in a rapidly developing city. Two case studies: the Biodiversity Network for Cape Town and the Conservation Implementation Plan for False Bay Strandveld. Pages 155-177 in D. Scott, H. Davies, and M. New, editors. Mainstreaming climate change in urban development: lessons from Cape Town. University of Cape Town Press, Cape Town, South Africa.

Holmes, P. M., and A. Pugnalin. 2016. The biodiversity network for the Cape Town municipal area C-plan and Marxan analysis: 2016 methods and results. Environmental Resource Management Department, City of Cape Town, Cape Town, South Africa. [online] URL: https://conservationcorridor.org/cpb/ Holmes and Pugnalin 2016.pdf

Holmes, P. M., A. G. Rebelo, C. Dorse, and J. Wood. 2012. Can Cape Town's unique biodiversity be saved? Balancing conservation imperatives and development needs. Ecology and Society 17(2):28. https://doi.org/10.5751/ES-04552-170228

ICLEI - Local Governments for Sustainability. 2012. Cape Town, South Africa: an urban biodiversity network. ICLEI Case Study 138. City of Cape Town, Cape Town, South Africa. [online] URL: http://old.iclei.org/fileadmin/PUBLICATIONS/Case Studies/ ICLEI cs 138 Cape Town.pdf

Khan, S., B. Lootvoet, and S. Vawda. 2006. Transcending traditional forms of governance: prospects for co-operative governance and service delivery in Durban's tribal authority areas. Transformation: Critical Perspectives on Southern Africa 62(1):84-117. https://doi.org/10.1353/trn.2007.0012

Madureira, H., F. Nunes, J. V. Oliveira, L. Cormier, and T. Madureira. 2015. Urban residents' beliefs concerning green space benefits in four cities in France and Portugal. Urban Forestry and Urban Greening 14(1):56-64. https://doi.org/10.1016/j.ufug.2014.11.008

Margules, C. R., and R. L. Pressey. 2000. Systematic conservation planning. Nature 405(6783):243-253. https://doi.org/10.1038/35012251

Margules, C. R., and S. Sarkar. 2007. Systematic conservation planning. Cambridge University Press, Cambridge, UK. 
Marx, C., and S. Charlton. 2003. Urban slums reports: the case of Durban, South Africa. Pages 195-228 in UN-Habitat, editor. Global report on human settlements 2003, the challenge of slums. Part IV: summary of city case studies. Earthscan, London, UK. [online] URL: https://www.ucl.ac.uk/dpu-projects/Global Report/ cities/durban.htm

McLean, C. T., L. E. Ground, R. G. C. Boon, D. C. Roberts, N. Govender, and A. McInnes 2016. Durban's systematic conservation assessment. eThekwini Municipality, Environmental Planning and Climate Protection Department, Durban, South Africa. [online] URL: http://www.durban.gov.za/City Services/ development planning management/

environmental_planning_climate_protection/Publications/Documents/ DurbansSystematicConservation.pdf

Miller, J. R., and R. J. Hobbs. 2002. Conservation where people live and work. Conservation Biology 16(2):330-337. https://doi. org/10.1046/j.1523-1739.2002.00420.X

Mittermeier, R. A., W. R. Turner, F. W. Larsen, T. M. Brooks, and C. Gascon. 2011. Global biodiversity conservation: the critical role of hotspots. Pages 3-22 in F. E. Zachos and J. C. Habel, editors. Biodiversity hotspots: distribution and protection of conservation priority areas. Springer, Berlin, Germany. https:// doi.org/10.1007/978-3-642-20992-5 1

Müller, N., P. Werner, and J. G. Kelcey, editors. 2010. Urban biodiversity and design. Wiley-Blackwell, Hoboken, New Jersey, USA.

O'Farrell, P. J., P. M. L. Anderson, D. C. Le Maitre, and P. M. Holmes. 2012. Insights and opportunities offered by a rapid ecosystem service assessment in promoting a conservation agenda in an urban biodiversity hotspot. Ecology and Society 17(3):27. https://doi.org/10.5751/ES-04886-170327

Patel, Z. 2005. Understanding environmental change in South African cities: a landscape approach. Transformation: Critical Perspectives on Southern Africa 57(1):24-40. https://doi. org/10.1353/trn.2005.0033

Pool-Stanvliet, R., A. Duffell-Canham, G. Pence, and R. Smart. 2017. Western Cape biodiversity spatial plan handbook. CapeNature, Stellenbosch, South Africa. [online] URL: https:// www.capenature.co.za/2017-western-cape-biodiversity-spatial-planhandbook-download/

Puppim de Oliveira, J. A., O. Balaban, C. N. H. Doll, R. MorenoPeñaranda, A. Gasparatos, D. Iossifova, and A. Suwa. 2011. Cities and biodiversity: perspectives and governance challenges for implementing the convention on biological diversity (CBD) at the city level. Biological Conservation 144(5):1302-1313. https://doi.org/10.1016/j.biocon.2010.12.007

Rebelo, A. G., P. M. Holmes, C. Dorse, and J. Wood. 2011. Impacts of urbanization in a biodiversity hotspot: conservation challenges in Metropolitan Cape Town. South African Journal of Botany 77 (1):20-35. https://doi.org/10.1016/j.sajb.2010.04.006

Roberts, D., and S. O’Donoghue. 2013. Urban environmental challenges and climate change action in Durban, South Africa. Environment and Urbanization 25(2):299-319. https://doi. org/10.1177\%2F0956247813500904
Skowno, A. L., C. J. Poole, D. J. Raimondo, K. K. Sink, H. Van Deventer, L. Van Niekerk, L. Harris, L. B. Smith-Adao, K. A. Tolley, T. A. Zengeya, W. B. Foden, G. F. Midgley, and A. Driver. 2019. National biodiversity assessment 2018: the status of South Africa's ecosystems and biodiversity. Synthesis report. South African National Biodiversity Institute, Pretoria, South Africa. [online] URL: http://hdl.handle.net/20.500.12143/6362

Stålhammar, S. 2021. Polarised views of urban biodiversity and the role of socio-cultural valuation: lessons from Cape Town. Ecosystem Services 47:101239. https://doi.org/10.1016/j.ecoser.2020.101239

Sutherland, C., V. Sim, S. Buthelezi, and D. Khumalo. 2016. Social constructions of environmental services in a rapidly densifying peri-urban area under dual governance in Durban, South Africa. Bothalia-African Biodiversity and Conservation 46(2):a2128. https://doi.org/10.4102/abc.v46i2.2128

Traditional Authorities Research Group. 1999. The role and future of traditional leaders in South Africa. Koers: Bulletin for Christian Scholarship 64(2-3):295-324. https://doi.org/10.4102/ koers.v64i2/3.505

Turok, I. 2001. Persistent polarisation post-apartheid? Progress towards urban integration in Cape Town. Urban Studies 38 (13):2349-2377. https://doi.org/10.1080/00420980120094551

Turok, I. 2012. Urbanisation and development in South Africa: economic imperatives, spatial distortions and strategic responses. International Institute for Environment and Development, London, UK. [online] URL: https://pubs.iied.org/10621iied

van Wilgen, B. W. 2013. Fire management in species-rich Cape fynbos shrublands. Frontiers in Ecology and the Environment 11 (S1):e35-e44. https://doi.org/10.1890/120137

Wilhelm-Rechmann, A., and R. M. Cowling. 2013. Local landuse planning and the role of conservation: an example analysing opportunities. South African Journal of Science 109(3-4):0026. https://doi.org/10.1590/sajs.2013/20120026

Wilkinson, C., M. Sendstad, S. Parnell, and M. Schewenius. 2013. Urban governance of biodiversity and ecosystem services. Pages 539-587 in T. Elmqvist, M. Fragkias, J. Goodness, B. Güneralp, P. J. Marcotullio, R. I. McDonald, S. Parnell, M. Schewenius, M. Sendstad, K. C. Seto, and C. Wilkinson, editors. Urbanization, biodiversity and ecosystem services: challenges and opportunities. Springer, Dordrecht, The Netherlands. https://doi. org/10.1007/978-94-007-7088-1 27

World Bank. 2016. Promoting green urban development in African cities: eThekwini, South Africa urban environmental profile. World Bank, Washington, D.C., USA. [online] URL: http://hdl.handle.net/10986/24037

Wright Wendel, H. E., R. K. Zarger, and J. R. Mihelcic. 2012. Accessibility and usability: green space preferences, perceptions, and barriers in a rapidly urbanizing city in Latin America. Landscape and Urban Planning 107(3):272-282. https://doi. org/10.1016/j.landurbplan.2012.06.003

Wynberg, R. 2002. A decade of biodiversity conservation and use in South Africa: tracking progress from the Rio Earth Summit to the Johannesburg World Summit on Sustainable Development. South African Journal of Science 98(5-6):233-243. 